\title{
TOURISTIC CLUSTERS IN BULGARIA \\ - EXAMPLE OF TERRITORIAL ORGANIZATION OF SERVICE ECONOMICS
}

\section{MILEN PENERLIEV}

\begin{tabular}{|c|c|}
\hline & $\begin{array}{l}\text { University of Shumen, BULGARIA } \\
\text { e-mail: penerliev@yahoo.com }\end{array}$ \\
\hline $\begin{array}{l}\text { RECEIVED } \\
\text { ACCEPTED }\end{array}$ & $\begin{array}{l}12 \text { January } 2016 \\
1 \text { April } 2016\end{array}$ \\
\hline $\begin{array}{l}\text { JEL } \\
\text { CLASSIFICATION }\end{array}$ & O43, L83 \\
\hline KEYWORDS & clusters, economic growth, economic effect, tourism \\
\hline ABSTRACT & $\begin{array}{l}\text { When it is impossible by its own efforts of a touristic company to develop great number of touristic activities /as } \\
\text { it is happened/ they have been realized from different organizations, companies and institutions. The relations } \\
\text { between them are very important. The common goals which they pursue are exactly enhancement the quality } \\
\text { of supplementary touristic activities and raising its profits. } \\
\text { A good example for territorial organization and interconnections of subjects working together with a common } \\
\text { goal in touristic branch is creation of touristic clusters. }\end{array}$ \\
\hline
\end{tabular}

\section{Nature of the touristic clusters}

Business clusters (in which group belong touristic clusters) have been known for a long time but they were introduced and detailed investigated by Michael Porter in 1990. He defines them as "groups of interconnected businesses, suppliers, and associated institutions in a particular field which are represented in given regions" According Shismanova - "business cluster is a self - organized network, a trust of companies, which produce 
supplementary products, use in common some production factors and technologies and are interconnected free in vertical and horizontal 'chains'".

Based on Shipovalova (2006) - "the cluster is a trust of companies in defined business fields, interconnected geographically and technologically in a particular territory" The same author underlines that it always involves scientific- research centers and educational centers. The main participants in a model cluster are shown on Figure 1.

According a New Zealand consulting agency Cluster Navigator - clusters are recognized as national, regional and commercial clusters. It has difference between touristic and common business clusters. Michael Porter terms it - "gratis effect". The difference is in that in a touristic cluster the perception of the visitor depends not only from the attractiveness of the initial attraction but and from the supplementary services as trade, entertainment, security, etc. That's why in the development of the touristic clusters are very important the supplementary touristic activities. As the participants in the cluster are interdependent the good presentation for each of them stimulates the success of the others.

\section{Essential teature}

It's happened - "cumulative effect". In touristic branch this " gratis effect " appears in different forms but the common particularity is this - the products and the services reach till the final customer in parallel and their influence is multilayer . For instance; food quality, quality of the services, guide's qualification, interior in the hotels, language training of the personnel, the safety of the destination etc.

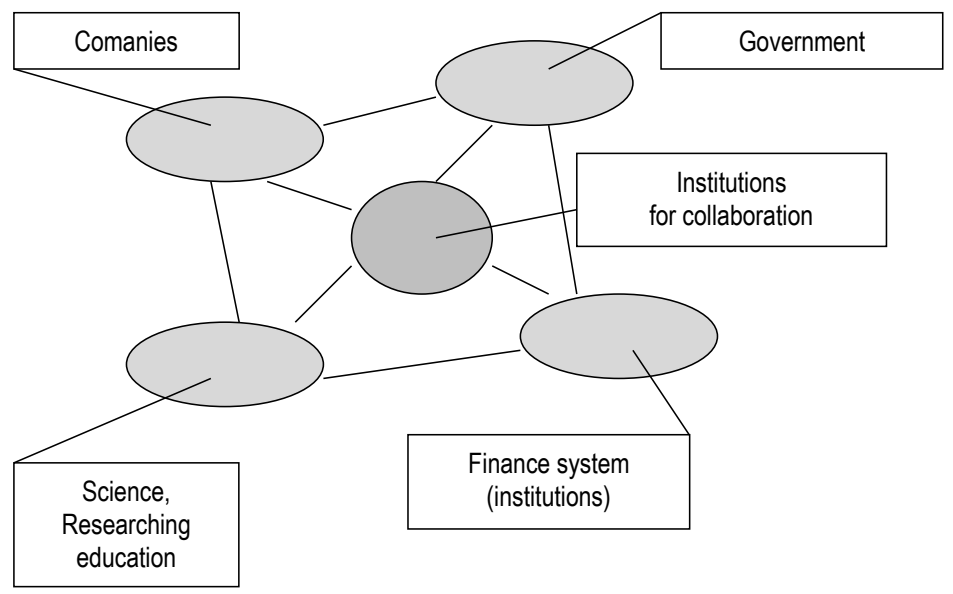

Figure 1. Business cluster structure

Source: based on Zlatev (2006).

This particularity of the touristic clusters is very important. If each participant realizes that its success depends from the performance of other participants then everyone will be ready for joint mutual work with the others in developing of a profitable touristic product. This way can be increased the quality, the productiveness, the innovation and thence consequently the profit. 
In this order we can take for granted the terms given aforesaid for business clusters as commonly valid and for touristic clusters. In their organization and functioning we must give render on the marked "gratis effect".

\section{Main "players" in touristic clusters}

According biggest consulting agencies in the range of business and touristic clusters worldwide the main groups economic objects involved in touristic clusters are:

- Main companies - companies directly offer their touristic products and services as spending the night, catering, transport, attractions, etc.

- Subsidiary companies - companies which offer supported products and services or are suppliers as: marketing, catering suppliers, building and facilities maintenance, etc.

- "Flexible supplementary infrastructure" - private, public and non-state organizations, agencies, and institutions assisted in developing and have influence as on the companies directly offered their services and products as and on the tourists.

- "Hard supplementary infrastructure" - companies and institutions provided implementation of normal touristic activities: maintenance and reconstruction of roads, utilities, waste treatment, communication, etc.

The relations and interconnections between these four groups are especially strong within a touristic destination. It is important each group to have its representative in the cluster as and to give maximum quality product as part of the common one.

\section{Good global practices in developing of touristic clusters}

Notorious in the global touristic practice are the touristic clusters in Costa Rica and Monterey, California USA (based on Zlatev, 2005).

In the beginning 90 - ties of XX century using the strong interest of tourists to ecologically pure destinations the government and the private business of Costa Rica have decided to strength their position as touristic destination. The state has developed and has built as touristic attractive destination and it has given more than $1 / 4$ of Gross Domestic Product (GDP). The touristic cluster "Costa Rica" is fact. All participants in the cluster work together in offering complete touristic product. For example in National park "Bara Honda" the tourists receive services especially developed for them:

- Restaurants with local kitchen food, motels and camping located in the core of the jungle, farm for growing deer, center for local arts and crafts, parking lots, guides. All these services have offered by local people which are some kind of employment. These services are offered in the edge of the park so to be preserved authentically aspect. Additionally participants from the cluster take part in planting rear wood species, in control and management risk assessment for forest fires, etc.

- Also are offered programs for cooking, English language, soil conservation, etc.

- In Monterey (situated on the coast of the Pacific ocean $200 \mathrm{~km}$ southern from San Francisco) after 2000 local community assigns to a consulting company to offer economic strategy for its development. After analysis of the local economy this company has suggested build three clusters - touristic, agricultural and scientific- educational clusters. It has begun implementation of one branding. The name of the region now in opposite of the old practice - all resorts have names separately, it has developed educational and qualification programs for the personnel in touristic branch, it has developed and put into practice unified 
marketing program, it has identified the alternative mechanisms for financing. The results have exceeded the expectations.

- Except raised profits it has increased the collaboration between companies which were rivals in the past. It has increased the relations between local administrative institutions and the business branches. It has grown the number of companies which want join the touristic cluster and no one company has left on its own will. It has increased inter- cluster relations, etc.

\section{Main questions in huilding of a touristic cluster}

The tourism cluster is possible. This is an opportunity to achieve a total positive result. Better development of the tourism industry. This important effect is achieved in time through certain steps. The most important of them are:

1. What kind of cluster do we create? This question has point of view - national, regional or commercial clusters. The choice seems is easy to do as in Bulgaria absent Strategy for development of the tourism as and the will for its profitable regulation. The commercial cluster couldn't create strong links in the touristic business in the country. Parts of activities of development and trade with touristic products are not developed at all. That's why the regional cluster is the only the right choice for creating touristic cluster on this stage in the country.

2. Where to locate a touristic cluster? This question is related to the location and geographical frames for a future cluster. Important advantages of the territory chosen for touristic cluster are:

- built modern communication infrastructure and transport,

- modern hotels and restaurants,

- presence of cultural, religion and entertainment centers,

- qualified personnel or presence of training centers for them,

- active non - government organizations and local authorities,

- presence of unique touristic resources for developing main and supplementary touristic activities.

3. Are there availability of prepared and motivated personnel in the chosen location of the future touristic cluster?

The idea, the process of building and developing of a cluster are not in the possibilities of a man or a organization. It is necessary presence of qualified specialists from private companies and economic institutions. Local authorities which are favorable and create necessary conditions for developing of a cluster. Educational and research institutions which are familiar with international standards in touristic branch and educate the personnel in innovation and creativity.

When there are such qualified personnel is easy to begin initial discussions on problems for the vision and the mission of a future cluster.

4. What preliminary information we need to create profitable regional touristic cluster?

There are different methods for building clusters. Commonly the initial activities are to "input parameters" in its building. This preparation include following:

- local economy analysis and determine the frame and the goals of the cluster- for this purpose are determined geographical borders of the cluster, the level of the local economy and are outlined the leading productions. It analyzes touristic resources in respect of definition the brand and the vision of the cluster, etc., 
- It has to create permanent board for defined period of time, which coordinates projects and programs within the cluster.

To summarize: In fact, these steps summarize the objectives and results. Indicate the nature and necessity of this cluster. They are logically related. Proper application is a guarantee of success. Here we show only the philosophy of this activity.

5. Where we can find financing for a future cluster?

Till beginning 2010 actual operative program of EU for non-refundable aid in creating clusters is OP "Competitiveness". In it with its priority axis no. 2 is possible financing of new or already existed clusters. It is acceptable financing till $50 \%$ from the project costs.

\section{An idea for a regional touristic cluster}

Shumen region is rich of cultural and archeological monuments. Here are Madara horseman monument, ancient capitals Pliska and Preslav and other places of interest which from now on will be objects for visits. The touristic cluster can be built on the base of tour operator companies, hotels, farmers and a local University. We can give it hypothetical name "From here begins Bulgaria" (Figure 2).

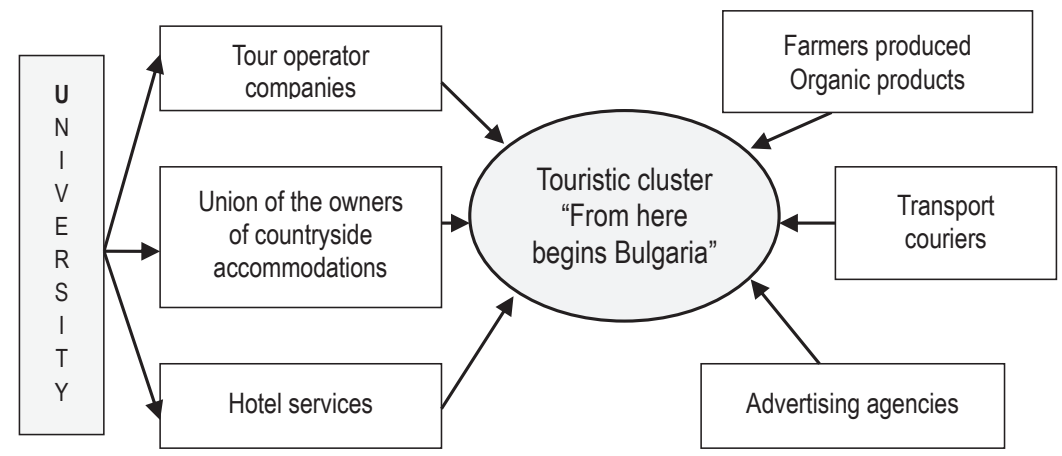

Note: Process of creating definite image, identification and association with trade mark, product or company.

Figure. 2. Model touristic cluster

Source: Penerliev (2011).

The following show how is defined the role of one of the participants - the University or other educational organization:

1. Development of syllabuses in Archeology and Cultural Tourism with view to the local conditions.

2. Developing courses for hotel services, restaurant personnel training, language courses, etc by order from business companies.

3. Direct participation in touristic activities and touristic product in lectures of entertaining Archeology in the beginning of each tour with duration more than one day.

4. Analysis characteristics of touristic flow, image assessment of touristic destination, quality of the touristic product, participation in its improvement, etc. 
5. Training activities on similar themes for interested companies and organizations from other geographical regions.

6. Organization of congress events on cultural - historical themes.

In such a cluster are leading resources. Their presence gives reason for launching this idea. In such territory compliment the presence of a university. Facilitates recruitment cluster gives him ideas for profiling and new programs. This strengthens synergies. This is the main result of the creation of clusters. In the services sector it is of great importance.

\section{Conclusions}

Main particularity in this cluster is - its participants to act together in synchrony till achieving the synergy effect. As the stress is on the cultural tourism and the role of supplementary activities in the tourism could be variable. The role of the other participants in this model cluster can be determined by everyone who is familiar whit this material. Good luck!

The model can be modified according the local particularities in a region.

In conclusion we can remark that the touristic clusters are a new imitative which is quite new even in global scale. Whoever undertakes such activities is predestinated on success.

\section{References}

Zlatev, B. (2005). Touristic clusters: world practices and conclusions for Bulgaria. Symposium Bulgarian tourism - management and effectiveness, Slavena, Varna (in Bulgarian).

Shipovalova, T., Polkovnikov, S. \& Berjnaya, T. (2006). Educational cluster- accelerator for development of the region. Symposium Problems and prospects of cooperation between countries of south-eastern Europe within context of Black sea economic cooperation and GUAM, Svishtov-Donetsk, pp. 266-271.

Shishmanova, M. (2005). Creation of clusters in territories suitable for tourism. Symposium Pirin book sheets issue 2, Blagoevgrad (in Bulgarian).

Penerliev, M. (2005). Universities for developing science parks - intercultural aspects. Intercultural in the Educational process, Shtip, Macedonia, pp. 21-27.

Penerliev, M. (2011). Geography in tourism. Teress proekt, Shumen (in Bulgarian).

www.eufunds.bg.

Cite this article aS: Penerliev, M. (2016). Touristic clusters in Bulgaria - example of territorial organization of service economics. European Journal of Service Management, 18 (2), 33-38. DOI: 10.18276/ejsm.2016.18-04. 